\title{
Educational constraints of immobility? Examining ethnic differences in student migration in Britain using Census microdata ${ }^{1}$
}

\author{
Nissa Finney \\ University of Manchester \\ The Cathie Marsh Centre for Census and Survey Research (CCSR) \\ Nissa.Finney@manchester.ac.uk
}

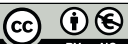

Received: February 2011

Accepted: April 2011

\begin{abstract}
This paper is situated in the emerging literature on minority/immigrant internal migration which grew from questions about the population dynamics behind ethnic residential segregation. This work has revealed both that migration within Britain is creating ethnic mixing and that there are considerable ethnic differences in levels and geographies of residential mobility. This paper contributes to our understanding of these differences by examining how being a student is related to residential mobility for different ethnic groups. It suggests that different residential decisions and migration norms at the point of entry into higher education partly explain ethnic differences in mobility. Using 2001 Census microdata (Sample of Anonymised Records), the paper finds that minority ethnic students are less mobile than their White counterparts, that being a student increases the probability of migrating for White British and Chinese young adults but decreases the probability of migrating for Pakistani and Black African young adults, and particularly so for Pakistani females. Given that it is common to migrate away from home for University study in Britain, this raises questions about equality of access to Higher Education. The examination of mobility in relation to key life events in young adulthood enables debates about ethnic geographies to move beyond the concern with segregation. The paper concludes with challenges for further research and a discussion of the policy implications of the findings in the context of current changes to Higher Education funding in the UK.
\end{abstract}

Key words: internal migration; ethnic group; student; lifecourse; census microdata; Britain.

1. Acknowledgements.- The 2001 Census Samples of Anonymised Records are provided through the Cathie Marsh Centre for Census and Survey Research (University of Manchester), with the support of the ESRC and JISC. Census output is Crown copyright and all tables containing Census data, and the results of analysis, are reproduced with the permission of the Controller of Her Majesty's Stationery Office and the Queen's Printer for Scotland. The author alone is responsible for the interpretation of the data. This research was sponsored by the Economic and Social Research Council through the Understanding Population Trends and Processes (UPTAP) programme, grant RES-16327-0011. I am grateful to the organisers and participants of the CED International Seminar on Demographic Behaviours and Social Integration of Immigrants (Barcelona, April 2010) at which this work was presented. 
Resum. La immobilitat imposa restriccions a l'educació? Examen de les diferències ètniques en la mobilitat dels estudiants de la Gran Bretanya a través de microdades censals

L'article se situa dins la bibliografia emergent sobre les migracions internes de les minories immigrants. Aquesta ha augmentat a partir de l'interès sobre la dinàmica poblacional després de la segregació ètnica residencial. L'estudi ha posat de manifest que la migració dins de la Gran Bretanya permet que es produeixin barreges entre ètnies i que existeixin diferències ètniques considerables en els nivells de mobilitat residencial i en els seus patrons territorials. Aquest article contribueix a entendre aquestes diferències a través de l'examen de la relació entre ser estudiant i la mobilitat residencial per diferents ètnies. S'hi suggereix que diferents decisions residencials i pautes migratòries d'accés a la universitat explicarien, en part, les diferències ètniques de mobilitat. A través de microdades censals (mostra anònima de dades) de 2001, s'arriba a la conclusió que els estudiants de les minories ètniques són menys mòbils que els seus homòlegs blancs. Ser estudiant incrementa la probabilitat d'emigrar, tant dels joves britànics blancs, com dels joves xinesos, però disminueix en la dels negres africans i la dels paquistanesos, especialment la de les dones d'aquesta darrera ètnia. El fet que a la Gran Bretanya, normalment, s'emigri lluny de la llar familiar per anar a la universitat, qüestionaria la igualtat en l'accés a l'educació superior. Relacionar la mobilitat i certs esdeveniments clau en la vida dels joves adults permet que els debats sobre geografies ètniques puguin anar més enllà de la preocupació per la segregació. L'article conclou plantejant reptes per a futures investigacions i amb un debat sobre les implicacions dels resultats sobre les polítiques en el context dels canvis que, en l'actualitat, pateix el finançament de l'educació superior al Regne Unit.

Paraules clau: migració interna; grup ètnic; estudiant; curs de vida; microdades censals; Gran Bretanya.

Resumen. ¿La inmovilidad impone restricciones a la educación? Examen de las diferencias étnicas en la movilidad de los estudiantes de Gran Bretaña a través de microdatos censales

Este artículo se sitúa dentro de la emergente bibliografía sobre las migraciones internas de las minorías inmigrantes, que ha crecido a partir del interés sobre la dinámica poblacional existente tras la segregación étnica residencial. El trabajo realizado ha puesto de manifiesto que la migración dentro de Gran Bretaña permite que se produzcan mezclas entre etnias y que existen considerables diferencias étnicas en los niveles de movilidad residencial y en sus patrones territoriales. Este artículo contribuye a entender dichas diferencias a través del examen de la relación entre ser estudiante y la movilidad residencial para diferentes etnias. En él se sugiere que distintas decisiones residenciales y pautas migratorias de acceso a la universidad explicarían en parte las diferencias étnicas de movilidad. A través de microdatos censales (muestra anónima de datos) de 2001, se llega a la conclusión de que los estudiantes de las minorías étnicas son menos móviles que sus homólogos blancos. Ser estudiante incrementa la probabilidad de emigrar, tanto de los jóvenes británicos blancos, como de los jóvenes chinos, pero disminuye la de los negros africanos y la de los pakistaníes, especialmente la de las mujeres de esta última etnia. El hecho que en Gran Bretaña normalmente se migre lejos del hogar familiar para ir a la universidad cuestionaría la igualdad en el acceso a la educación superior. Relacionar la movilidad y ciertos acontecimientos clave en la vida de jóvenes adultos permite que los debates sobre geografías étnicas puedan ir más allá de la preocupación por la segregación. El artículo concluye planteando retos para futuras investigaciones y con un debate sobre las implicaciones de los resultados sobre las políticas en el contexto de los cambios que en la actualidad sufre la financiación de la educación superior en el Reino Unido.

Palabras clave: migración interna; grupo étnico; estudiante; curso de vida; microdatos censales; Gran Bretaña. 
Résumé. L'immobilité impose-t-elle des contraintes à l'éducation? Examen des différences ethniques de la mobilité des étudiants en Grande-Bretagne à travers des micro-données du recensement

Cet article se situe dans l'émergente littérature sur la mobilité interne des minorités/immigrants, qui est accrue en conséquence de l'intérêt par les dynamiques démographiques derrière la ségrégation ethnique résidentielle. L'analyse démontre que la migration interne favorise les mélanges ethniques et qu'il y a de considérables différences entre les ethnies par rapport aux niveaux de mobilité résidentielle et sa distribution géographique. Cet article contribue à comprendre ces différences à travers l'examen de la relation entre le fait d'être étudiant et la mobilité résidentielle, pour différents groupes ethniques. Les résultats suggèrent que différentes décisions résidentielles et normes migratoires d'accès à l'Université expliqueraient, en partie, les différences de mobilité entre ethnies. À travers des micro-données du recensement de 2001 (échantillon de données anonymes), on a découvert que les étudiants des minorités ethniques sont moins mobiles que leurs homologues blancs. Être étudiant augmente la probabilité de migrer des jeunes britanniques blancs et des chinois, mais diminue celle des noirs africains et des pakistanais (et en particulier, pour ce dernier groupe, celle des femmes). Le fait qu'en Grande-Bretagne normalement on migre pour aller à l'université, poserait des questions sur l'égalité des chances d'accès à l'éducation supérieure. Mettre en relation la mobilité et certains événements clés dans la jeunesse permet que les débats sur les géographies ethniques puissent aller plus loin dans la préoccupation pour la ségrégation. L'article finit par exposer des défis pour des recherches futures et en proposant un débat sur les implications des résultats sur les politiques dans le contexte des changements actuels de financement de l'éducation supérieure au Royaume-Uni.

Mots clé: migration interne; groupe ethnique; étudiant; cours de vie; micro-données du recensement; Grande-Bretagne.

\begin{aligned} & \multicolumn{2}{c}{ Summary } \\ & Introduction Definitions of ethnic group, internal \\ & Lifecourse understandings of differential migration and young adults \\ & mobility of minorities Results \\ & Ethnicity and higher education choice Discussion and conclusion \\ & in Britain References \\ & Methods \end{aligned}

\section{Introduction}

Interest in the internal migration of ethnic minority populations in Britain has arisen in recent years out of debates about residential segregation. In the context of urban disturbances in some English towns in 2001 and terrorist attacks in the US (2001), England (2005) and elsewhere (e.g. Madrid, 2004) political concerns emerged about divisions, residential and otherwise, between communities along lines of ethnicity (Cantle, 2001; Phillips, 2005). These discourses have continued into the second decade of the twenty first century within the framework of national security and national identity. For example, 
in a speech in February 2011 Prime Minister David Cameron commented that «Under the doctrine of state multiculturalism, we have encouraged different cultures to live separate lives, apart from each other and apart from the mainstream. We've failed to provide a vision of society to which they feel they want to belong. We've even tolerated these segregated communities behaving in ways that run completely counter to our values... We need a clear sense of shared national identity that is open to everyone» (Cameron, 2011).

Academics have responded by debating the levels and changes in ethnic residential segregation (Johnston et al., 2002; Simpson, 2007; Peach, 2009), the meanings of patterns of residence by ethnic group (Phillips, 2006; Kalra and Kapoor, 2009; Bolt et al., 2010) and the demographic processes shaping local ethnic group populations (Simpson et al., 2006; Finney and Simpson, 2009; Stillwell, 2010). Work examining the patterns and processes of subnational ethnic group population change has argued that the meaning of residential 'segregation' cannot be fully understood without clarity about how natural population change and migration are operating locally to change the ethnic make-up of neighbourhoods. This work has demonstrated that although the geographies of migration within Britain are different across ethnic groups because of their uneven geographical distribution, there are common processes of migration in operation, namely dispersal from co-ethnic concentrations and movement away from the most urban areas (Simpson and Finney, 2009; Stillwell, 2010; Muñoz, 2010; Simon, 2010). The out-movement of minority populations is somewhat balanced by the in-situ natural growth of these young population groups (Finney and Simpson 2009). Nevertheless the picture is one of increased and increasing ethnic mixing.

This body of work, whilst responding to the segregation debate, has also raised questions about exactly what it is about ethnicity that may influence both the levels and geographies of residential mobility within Britain. I have suggested elsewhere that a lifecourse approach is helpful (Finney, 2011), for example in understanding migration decisions in young adulthood. In this paper I extend this argument by focusing on the migration experiences of young adults of different ethnicities who are students. The aim of the paper is to better understand the role of ethnicity in shaping migration patterns and, in addition, how perceptions about migration may affect Higher Education choice processes. There follows a review of work exploring how ethnicity (or immigrant origin) may affect mobility through the lifecourse and a review of ethnicity and moving to higher education (University) in Britain. The methods and definitions used for analysing ethnic differences in residential mobility using UK 2001 Census microdata are then outlined. The results are presented in three sections: first, variations in mobility for students and non students of different ethnic groups (by age and sex) are considered; second, likelihood of migration is modelled to test for a student effect; and third, the model is extended to examine the relation between gender and student status. The concluding discussion considers theoretical and methodological challenges for future research. 


\section{Lifecourse understandings of differential mobility of minorities}

Studies of internal migration in population geography and demography have in recent years been influenced by lifecourse theories (usefully reviewed by Bailey, 2009) and re-theorisation of family. The aim has been to move beyond economic rationality explanations of migration and understand diversity of experiences. Despite recognition (Bailey and Boyle, 2004) of the need to understand ethnic differences in migration experience, little work has to date engaged with this issue.

A lifecourse approach to internal migration is concerned with how life events (or transitions) such as beginning or ending study or work, having a child, forming or dissolving a partnership, are associated with moving house (Rabe and Taylor, 2009). This paper is interested in how this association differs between ethnic groups. Studies of cross-national heterogeneity in transitions to adulthood can provide theoretical direction for the study of sub-populations. For example, Fussell et al. (2007: 411) investigated inter-national heterogeneity in transition to adulthood by comparing experiences in the USA, Canada and Australia. They found country differences in the transition to social adulthood which they attributed to «a function of difference in values and marriage markets» but recognised that their explanations would benefit from «analysis of subpopulation within the United States since distinct ethnic groups exhibit very different family formation patterns» (Fussell et al., 2007: 411; Gauthier, 2007).

Of more direct relevance are studies of ethnic differences in migration in young adulthood which focus on family influence and cultures of home leaving. These studies are situated in family migration literatures which are concerned with the implications of changing family arrangements for residential mobility (Bailey and Boyle, 2004). Mulder (2007) sets an agenda for this research, arguing that the family context and inter-generational transfers for migration decisions may be particularly important for non-western migrants who tend to be both more mobile and place greater importance on family than their western counterparts. Intergenerational transfer can have an effect on migration in terms of ethnic-specific preferences and behaviours (e.g. strength of family ties, traditions of home leaving) and in terms of status inheritance (socio-economic resources).

De Valk and Billari (2007) examine the effect of intergenerational transfer on homeleaving for young adults of different ethnic groups in the Netherlands. They find few ethnic differences in factors associated with staying in the family home but greater ethnic difference in pathways out of the parental home. For example, «being in a union was much less associated with leaving home for Moroccan, Antillean and especially Turkish young adults than was the case for the Surinamese and the Dutch» (de Valk and Billari, 2007: 213). Ethnicity has also been found to affect the timings and pathways of homeleaving in a North American context (Mitchell et al., 2004; Goldschneider and Goldschneider, 1988, 1997). In the US Hispanics have the highest rates of leaving home for marriage followed by Whites with Blacks having considerably lower rates. 
Whites have higher rates of leaving home for job-related reasons than Blacks or Hispanics. The probability of leaving home to attend school (university) is consistently lower for Blacks than Whites over time: «Leaving home for higher education is the family process most closely linked with the reproduction of socioeconomic differences... going away to school... remains difficult [for Blacks] in a deeply segregated society» (Goldschneider and Goldschneider, 1997: 305).

Studies also point to the importance of examining gender: women can be expected to show greater family solidarity than men and are more likely to move long distances for reasons of marriage (Mulder, 2007). In the Netherlands, girls of Turkish and Moroccan origin are likely to leave home at the point of marriage whereas Dutch girls tend to leave home before marriage to live independently (de Valk and Billari, 2007).

\section{Ethnicity and higher education choice in Britain}

In the UK, entry to higher education is a common homeleaving pathway (Faggian et al., 2006). Given the findings of the studies discussed above, it is plausible to suggest ethnic differences in migration norms associated with being a student. Compulsory schooling ends after year 11, usually at the age of $16^{2}$. Young people then have the option to continue studying in schools or colleges via academic and vocational routes (further education). Further education qualifications are a pre-requisite for Higher Education study at University, usually for degree qualifications. It has been common, since the expansion of Britain's Higher Education system in the mid 20 ${ }^{\text {th }}$ century, for University students to live away from home and to study at a University away from the home town. Thus, student migration has resulted in 'studentification' of parts of British cities (Smith and Holt, 2007).

Since the Labour government took power in 2007 there have been fundamental changes to the Higher Education (HE) system in the UK which have continued under the Conservative-Liberal Democrat administration elected in 2010. Two of these changes have implications for University choice and, concordantly, residential choice of young adults who are students: first, the programme to widen participation in Higher Education; second, the introduction of tuition fees for University courses.

The 'widening participation' agenda aims «to promote and provide the opportunity of successful participation in HE to everyone who can benefit from it» including the objective "[t]o stimulate and sustain new sources of demand for $\mathrm{HE}$ among under-represented communities and to influence supply accordingly» (HEFCE, 2009: 18). Widening participation is one of the strategic aims of the Higher Education Funding Council who state that it

2. There are some differences between the education systems of the four constituent countries of the UK (England, Wales, Scotland and Northern Ireland). In particular, the Scottish system differs in the breadth of subjects studies and qualifications gained pre-higher education and in the length of degree courses. 
«is vital for both social justice and economic competitiveness. We also believe in the benefits of learning in an environment with a diversity of students and staff» (HEFCE, 2009: 19). In 2002 the Labour government under Tony Blair announced the target of at least 50 percent of young people entering higher education by the end of the decade. The under-represented groups of concern were primarily lower socio-economic groups. The over-representation of ethnic minority populations in low socio-economic groups means that they are a particular target for the policy.

Alongside the widening participation agenda and, arguably, somewhat contrary to it, tuition fees for higher education were introduced and maintenance grants reduced. In 1998 university fees were introduced at $£ 1,000$ per year later rising to $£ 3,290$. In 2010 it was announced that direct government funding for university teaching would be cut and universities would be able to charge up to $£ 9,000$ per year for tuition fees. The extra cost of higher education study has implications for university choice, not just in terms of decisions based on the price of a course but on costs of living. Staying in the family home is one way to reduce the overall cost of higher education.

It can be argued that these changes have had (and will continue to have) differential effects across ethnic groups although "[a]mongst the preoccupation with gender and class within research into higher education in Britain, the operations of 'race' and ethnicity have been largely neglected" (Reay et al., 2001: 857). Participation of students from minority ethnic communities in HE is higher than for students from White communities with around a fifth of firstdegree students being from minority ethnic backgrounds (Equality Challenge Unit, 2009; HEFCE, 2010). However, attainment is markedly lower for minority students even after controlling for factors which would be expected to have an impact on attainment (Broecke and Nicholls nd; Equality Challenge Unit, 2009). There are also differences in institutions attended with minorities being over-represented in new universities with lower entry profiles (Reay et al., 2001; HEFCE, 2010). In 2002 at least 20 percent of students of minority ethnic groups came from and studied in London compared to 3 percent of White students. More White students stayed in institution-maintained accommodation (halls of residence) in their first year of study than students of other ethnic groups (HEFCE, 2010). Faggian et al. (2006), in an analysis of migration for study and following graduation, concluded that Blacks and Asians were less likely than others to move away from their home region for study and to move again following graduation. This has implications for graduate employment opportunities which are seen to be enhanced by residential mobility.

These differences in participation and institution have implications for migration because they represent different choice processes and opportunity structures (Reay et al., 2001: 871): «despite increasing numbers of working-class students, in particular those from minority ethnic backgrounds, applying to university, for the most part, their experiences of the choice process are qualitatively different to that of their more privileged middle-class counterparts... The combination and interplay of individual, familial and institutional factors 
produces very different 'opportunity structures'». Ball et al. (2002) suggest that university choosers can be broadly categorised into two groups (Table 1): contingent and embedded choosers. Within this categorisation ethnicity acts in two ways on choice. First, in the consideration of the ethnic mix of the destination; second, in terms of socio-spatial perceptions. For contingent choosers "[s]patial horizons of action are limited, partly for reasons of cost and partly as a result of concerns about ethnic fit and ethnic mix and the possibility of confronting racism... Leaving London or leaving home is rarely an option for these students» (Ball et al., 2002: 338). In addition, family influence on higher education decisions has been found to be greater for minorities than for Whites, particularly for Asians and particularly for females (Connor et al., 2004). The relatively limited experience of older ethnic minorities of higher education study (in the UK) reduces the likelihood of intergenerational transfer of norms of university study (Brooks, 2003) which are evident for the embedded chooser.

Table 1. Ethnicity and Higher Education choice: a typology of choosers

\begin{tabular}{ll}
\hline Contingent choosers & Embedded choosers \\
$\begin{array}{l}\text { Practical considerations } \\
\text { Finance is a key concern and constraint }\end{array}$ & Finance is not an issue \\
\hline $\begin{array}{l}\text { Level of abstractedness of decision } \\
\text { Choice is distant or 'unreal' }\end{array}$ & $\begin{array}{l}\text { Choice is part of a cultural script, } \\
\text { a 'normal biography' } \\
\text { Choice is specialist/detailed } \\
\text { Choosing is short term and weakly }\end{array}$ \\
$\begin{array}{l}\text { Choosing is long-term and often } \\
\text { an incomplete or incoherent narrative }\end{array}$ & $\begin{array}{l}\text { Chelates to vivid and extensive 'imagined } \\
\text { futures' - part of a coherent and planned } \\
\text { narrative }\end{array}$ \\
$\begin{array}{l}\text { First-time choosers with no family } \\
\text { tradition of HE }\end{array}$ & $\begin{array}{l}\text { 'Followers' embedded in a 'deep } \\
\text { grammar of aspiration' which makes }\end{array}$ \\
\hline
\end{tabular}

\section{Information sources/networks}

Choice uses minimal information

Minimal support (social capital) is used Parents as 'onlookers' or 'weak framers'/ mothers may give practical support on families making the choice

\section{Geographical imaginations}

Ethnic mix is an active variable in choosing

Narrowly defined socioscapes and spatial horizons - choices are 'local'/distance is a friction
Choice is based on extensive and diverse sources of information

Extensive support (social capital) is used

Parents as 'strong framers' and active participants in choice

Source: Adapted from Ball et al., 2002.

Ethnic mix is marginal or irrelevant to choice

Broad socioscapes and social horizons - choices are 'national'/distance is not an issue 


\section{Methods}

\section{Data}

Description and explanation of patterns of migration in Britain for young adults of different ethnic groups demands data that are not abundantly available. A lifecourse approach will ideally examine the synchronicity of young adult life events (beginning study, forming a partnership, getting married, having children) with residential migration (Mulder and Wagner, 1993). This demands longitudinal data. However, British longitudinal datasets lack the required combination of variables (migration, ethnicity, life events) and sufficient sample size for young adult ethnic group populations.

The British Household Panel Survey (BHPS) is an extensive national annual survey of around 10,000 individuals. The BHPS has been used for analysis of residential mobility (e.g. Rabe and Taylor, 2010) but not where the focus is on minority ethnic groups which constitute less than 10 percent of the population, or young adults by ethnic group. The Labour Force Survey includes only limited migration information and the data are only longitudinal over 5 quarters which is insufficient to capture the relation between migration and young adult life events. The Longitudinal Survey of Young People in England (LSYPE) has adequate variables for the questions posed here and a sample size of around 15,000 households. However, the sample is too young for this study, being those born in 1989/1990 (age 20 in 2010). In sum, existing longitudinal surveys have sample sizes which are too small to allow analysis broken down by ethnic group and age and in some cases the populations sampled are inappropriate and migration and life events are not sufficiently captured.

Thus, census data provides the source for this paper. The 2001 Census is outdated and cross-sectional but has the required variables (and geographical details) and, crucially, large samples in the microdata. This paper uses the UK 2001 Census Individual Sample of Anonymised Records (SAR). This is a 3\% sample of the population with approximately 1.84 million records.

\section{Modelling internal migration}

The analyses that follow model whether an individual (in this case a young adult) has migrated or not. As the outcome variable is dichotomous (migrant/ non-migrant) multiple logistic regression modelling is used (Hosmer and Lemeshow, 2000). This allows examination of the associations of certain social or demographic positions — such as being a student or being married - with internal migration, whilst controlling for other characteristics of an individual.

The selection of variables in the models was guided by the literature on characteristics of migrants. Since the 1930s, numerous studies have distinguished the individual and household characteristics of migrants in Britain from those of non-migrants (Leon and Strachan, 1993). Generally, it has been found that young people, males, private renters, students, those who are unemployed, those in good health, those living in small households, those of 
higher socio-economic status, those with higher levels of education and those without children are most likely to migrate (See, for example, Hamnett, 1991; Champion and Fielding, 1992; Halfacree et al., 1992; Leon and Strachan, 1993; Brimblecombe et al., 1999; Bailey and Livingstone, 2005; Finney and Simpson, 2008). On the basis of this literature the models were devised and were then developed through examination of the relationship between internal migration and the explanatory variables of interest to ensure that the results in the models presented are robust. The models were refined such that only significant variables were included and the addition of variables improved the fit of the model (as indicated by decreases in the -2 Log Likelihood value and increases in Pseudo R squared values). In the final models, the variables used to predict internal migration of young adults are the explanatory variables of interest: ethnic group and whether the individual is a student; and a set of control variables: sex, tenure, qualifications, socio-economic classification and whether the individual is an immigrant (born outside the UK).

The results are presented in four models (Tables 6 to 9). The main model (Table 6) predicts the likelihood of an individual migrating using the variables listed above. The model is then developed through the addition of interactions between student status and ethnicity (Table 7) with the aim of testing whether being a student acts differently with respect to migration across ethnic groups. This model is then run separately for the three age groups 16-19, 20-24 and 25-29 (Table 8) to see if the relationship between ethnicity, student status and migration varies across young adult ages. The final model (Table 9) is based on Table 6 but run separately for each ethnic group with an interaction between sex and student status. This aims to test whether the relationship between student status and migration differs for males and females, and how this varies across ethnic groups.

\section{Definitions of ethnic group, internal migration and young adults}

\section{Ethnic group}

'Ethnic group' is used in this paper to identify groups who differ in terms of their ancestral (im)migration history, their cultures, customs and traditions, their religion and their colour. Particular age structures and levels of education and wealth are associated with different ethnic groups. There is much debate about the meaning of the UK census ethnic group categories, and the extent to which they successfully capture the ethnic diversity of Britain (Aspinall, 2000; Burton et al., 2010). Ethnic group information can be viewed as a useful indicator of certain individual and group characteristics, but in no way can it provide an essential character for a set of people nor full explanations for differing experiences.

The 2001 Census SAR gives 13 ethnic groups. The analysis presented in this paper retains this full 13 group classification. The detail this allows, for example in providing three 'White' groups and the Indian, Pakistani and Bangladeshi groups separately rather than as a broad 'South Asian' group, 
is intended to maximise the homogeneity of ethnic groups in terms of the characteristics that may influence internal migration. For example, whether an individual is an international migrant is known to affect their subsequent within-country migration. Retaining ethnic distinction for groups that are known to have different immigration histories thereby enables more nuanced interpretations of internal migration differences. This is the case for the White groups, where the White Other group has a much larger proportion of immigrants $(79 \%)$ than the White British group (2\%) and a more recent immigration history. Similarly, Bangladeshi immigrants to the UK are more recent (main period of arrival 1980-1988, see Peach, 1996) than Pakistanis (main period of arrival 1965-1979) and Indians (main period of arrival 1965-1974).

Although there is considerable heterogeneity within the ethnic groups captured by the census, there are some factors which describe well the differences between groups. Two of these factors that are important for understanding migration patterns are age structure and geographical distribution. Figure 1 show the proportion of each ethnic group in each of six age groups. The bars representing ethnic groups are arranged in order from left to right of decreasing proportion of group population under the age of 30 . Two thirds or more of the Black African, Pakistani, Bangladeshi and Mixed groups are under the age of 30 compared with a third of the White British population and a fifth of the White Irish population. The relative youth of the Black African and Asian groups is a result of their immigration history, with young adult immigrants having arrived since the 1960s. The youth of the Mixed group represents this group's 'new' status, made up of children of parents of different ethnicities

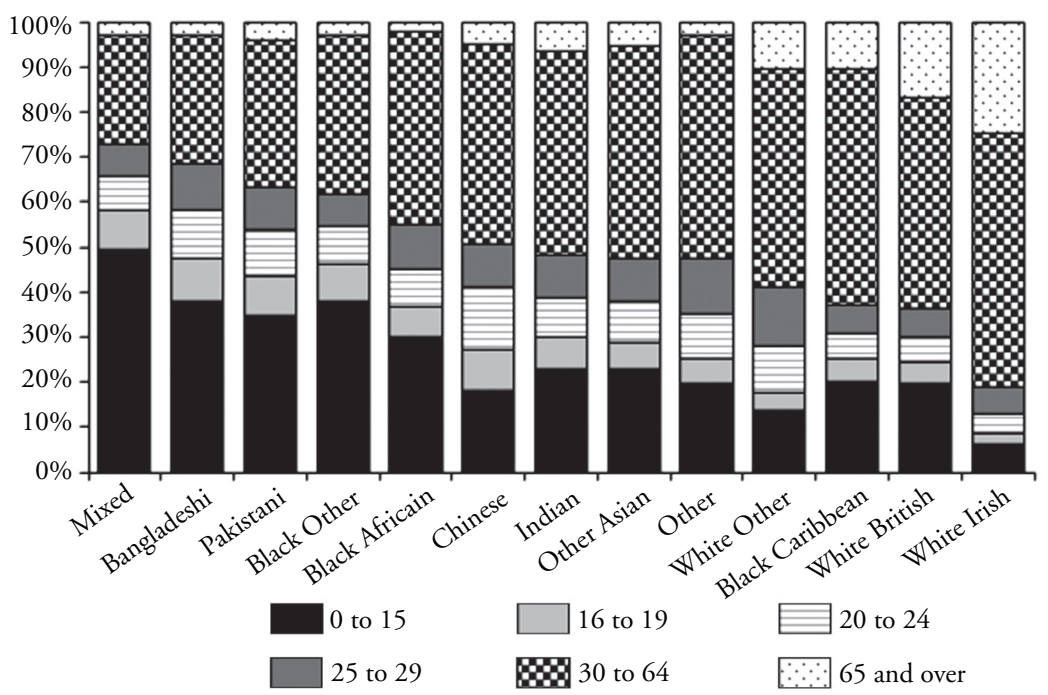

Figure 1. Age structure of ethnic groups in Britain, 2001.

Source: UK Census 2001 SAR. 


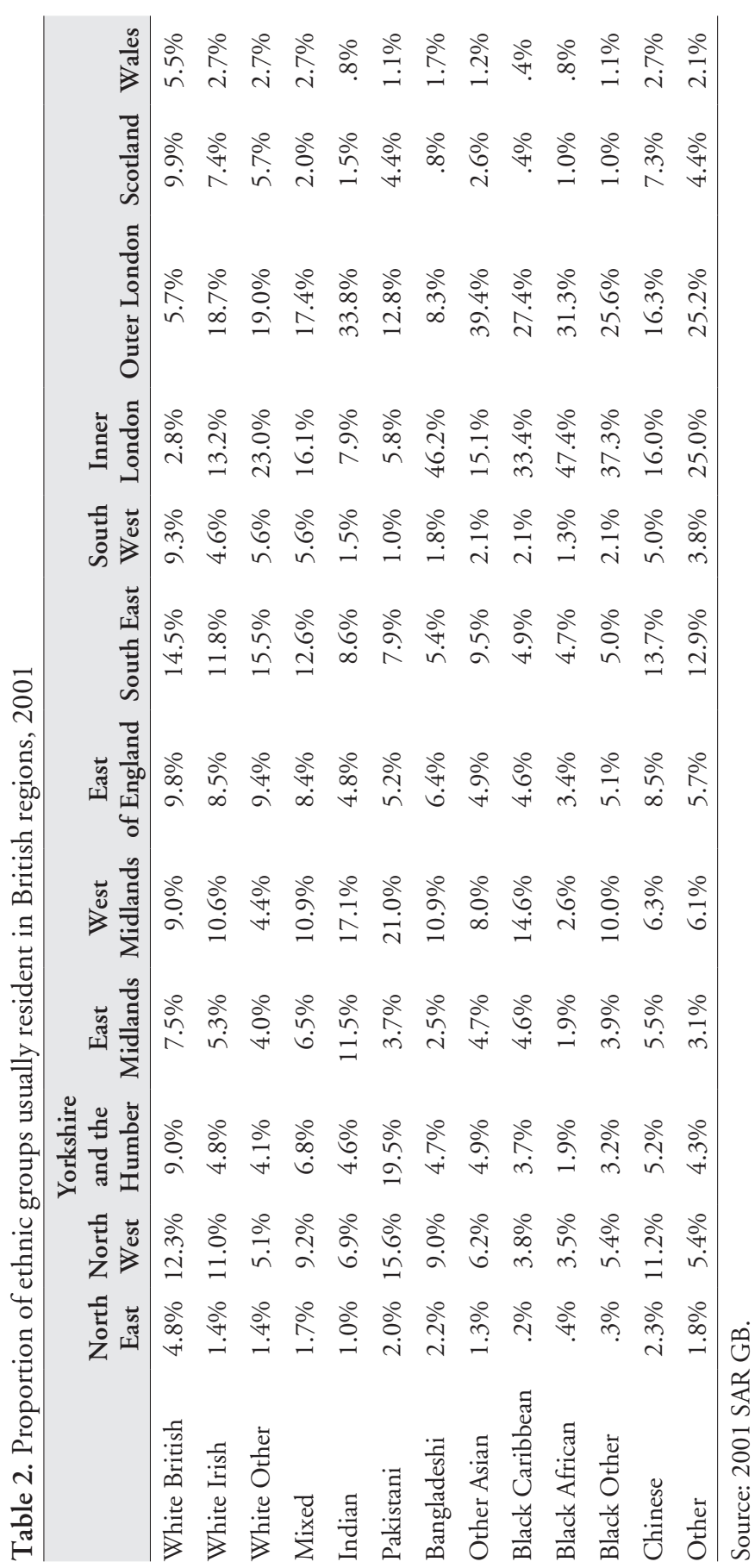


(and representing, therefore, the most intimate form of ethnic mixing). The differing age structures of ethnic groups in Britain, as will be shown below, are important for understanding ethnic differences in internal migration.

Table 2 shows the distribution of ethnic group populations across the regions of Britain. Groups other than the White British are over-represented in Inner and Outer London. This is particularly the case for the Bangladeshi and Black African groups: 46 percent and 47 percent of their populations respectively reside in Inner London (and an additional 8 percent and 31 percent respectively in Outer London). The South Asian groups are over-represented in the Midlands and the Pakistani population in the North West and Yorkshire and the Humber. Minority ethnic groups are under-represented in other regions of England and in Scotland and Wales.

\section{Internal migration}

UK census data on migration are based on a question about place of residence one year prior to census day. If this is different from the address on census day, the individual is considered to have migrated in the year prior to the census. This is transition migration data rather than event data; it captures moves within a given time period (in this case 2000-2001) rather than every migration event. The main limitation of this measure of migration for this study is, as discussed above, there is no information about the relative timings of migration and changes in individual circumstances such as getting married.

The focus of this paper is internal migration, that is migration within Britain: migrants are people who changed their place of residence in the year prior to the census and who lived within Britain at both timepoints. Internal migration, also termed residential mobility, is a specific type of mobility, where the focus is on a semi-permanent or permanent change of residence.

\section{Young adults}

Young adulthood is the period in life following adolescence in which an individual moves on from dependence on parents or guardians to lead an independent life. It is well established that residential mobility is high in young adulthood and events associated with migration occur disproportionately in this period of life (Halfacree et al., 1992; Bonney et al., 1999). In the transition to adulthood, or "years in between", most young adults "move from the security/insecurity of their families through a series of usually more insecure tenures, relationships and occupations» (Thomas and Dorling, 2007: 88).

Lifecourse research places focus on life events rather than age groups or life stages, and relates these life events to life outcomes, experiences and attitudes, taking into account the complexities of individual pathways through periods of the lifecourse such as young adulthood (Bailey, 2009). Thus, the boundaries of 'young adulthood' are fuzzy. In the analyses presented here, in the absence of synchronous event data, the population of interest is selected 
on the basis of age. The age band has been defined to capture the section of the population which is most mobile; and the section of the population for which ethnic differences in levels of internal migration are greatest.

The limited body of work on ethnic differences in levels and geographies of internal migration in Britain has identified age as an important factor in understanding ethnic differences (Stillwell and Hussain, 2008; Simpson and Finney, 2009). Most generally, the young age structure of minority groups is a primary reason for their overall internal migration rates being higher than those of White Britons. Furthermore, each ethnic group demonstrates an agemigration profile in which people aged between 20 and 29 are the most mobile internal migrants (Table 3, Figure 2). In the year prior to the last census, Pakistani and Bangladeshi young adults migrated least within Britain with migration rates around 15 percent. The highest rates are for the White Irish, White Other and Chinese groups of which at least four in ten people aged 20-24 migrated within Britain between 2000 and 2001.

Notwithstanding the common pattern of young adults being most mobile in each ethnic group, and the younger age structure of non-White groups leading to their overall higher internal migration rates, ethnic differences in levels of migration are greatest for young adult ages (Figure 1). It is fruitful, therefore, for a study of ethnic differences in internal migration to focus on the ages of greatest difference, in this case between 16 and 29. The analyses takes this age group as a whole and in 3 groups (16 to 19,20 to 24 and 25 to 29) which are taken to reflect different stages in transition to adulthood.

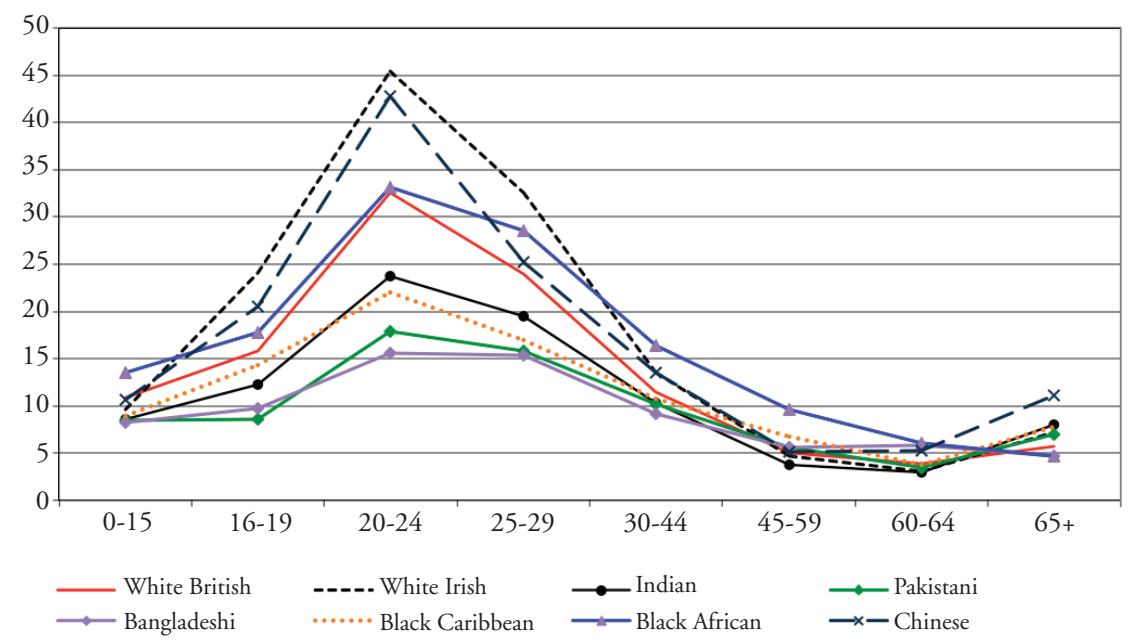

Figure 2. Within Britain migration rates (\%) 2000-2001 by age for selected ethnic groups. Source: 2001 Census SAR, GB. Numerator is population who changed address in the year prior to the census; Denominator is 2001 population in each age/ethnic group. 


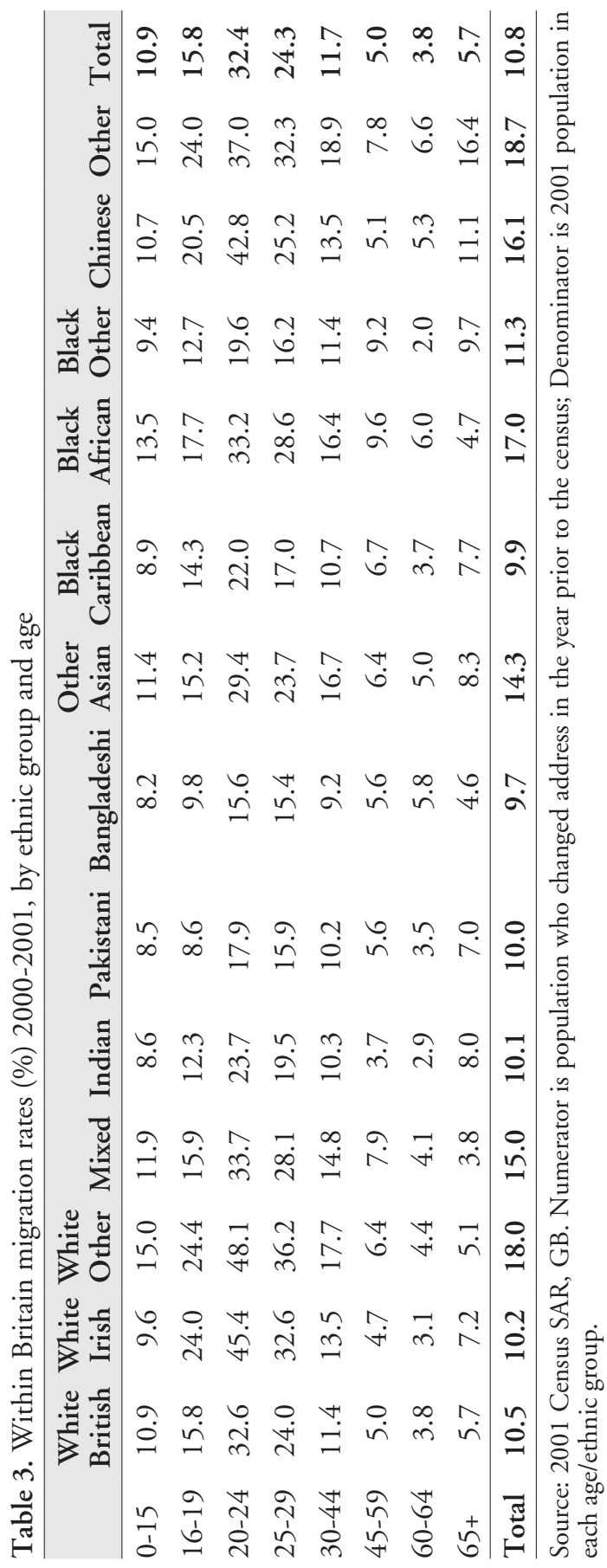




\section{Results}

Mobility and immobility amongst students of different ethnic groups

In considering whether differential choice mechanisms for higher education study are partly responsible for the ethnic differences in levels of internal migration of young adults in Britain the starting point is to examine whether there are differences in levels of mobility between students of different ethnic groups. Table 4 first presents the proportions of each ethnic group who are full time students. For the population overall and people aged 16-29 the proportions of students are highest for the non-White groups. Around a quarter of Asian and Caribbean young adults are students compared to fifteen percent of their White British counterparts. The figures for the Black African and Chinese groups are particularly striking: 36 percent and 52 percent of people aged 16-29 in these groups respectively are full time students.

There are also notable differences between ethnic groups in the migration rates of students (Table 5). For the 16-19 age group migration rates are of the same magnitude as those for the population as a whole (see Table 3). Given that the majority of students in this age group will be in school or college and predominantly living in the family home, this suggests that migration of

Table 4. Proportions of ethnic group populations that are students (percent), 2001

Percent who are full time students

a) All people

White British

3.8

3.4

10.4

14.4

10.1

12.4

12.1

11.9

Other Asian

16.3

Black African

11.6

Chinese

23.3

Other

18.1 b) People aged 16-29

28.6

26.2

23.2

31.0

25.6

51.8

40.9

Source: 2001 Census SAR. 


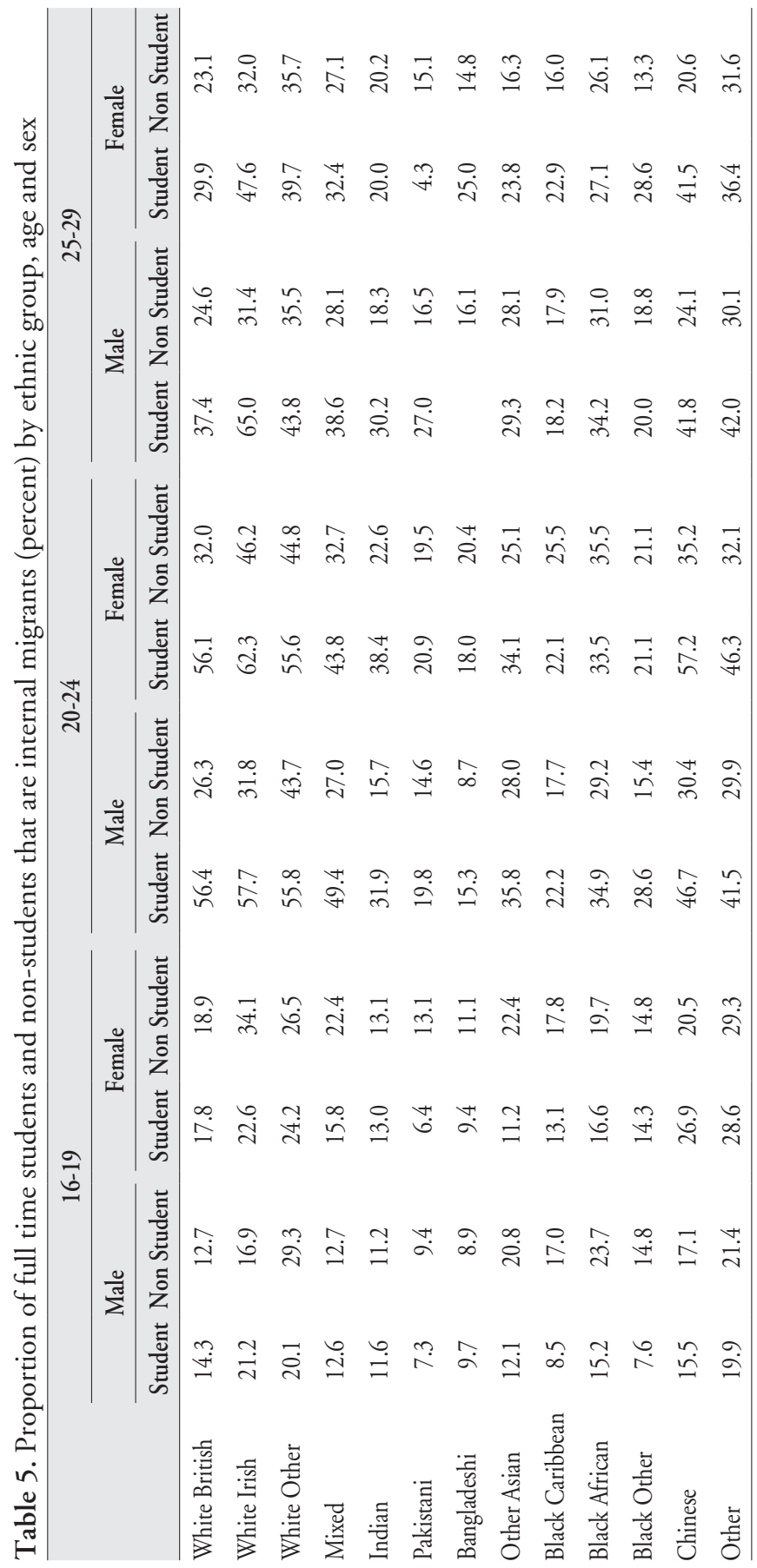


these young adults may be part of family or household movement rather than independent migration. For the 20-24 and 25-29 age groups several features of table 5 are notable: first, levels of mobility of students are high and over 50 percent for some ethnic groups and this is particularly the case for the 20-24 year olds; second, student mobility is, almost without exception, higher than mobility of non-students for males and females; third, there are few differences in levels of student mobility between males and females; fourth, the White groups have the highest levels of residential mobility and the Pakistani, Bangladeshi and Black Caribbean have the lowest levels of residential mobility. There is one very striking figure in the table, for Pakistani females who are mature students (age 25-29). Their rate of internal migration is 4.3 percent, lower than their non-student counterparts and males of the same age and lower than the Pakistani ethnic group as a whole (10 percent; table 3$)$ and the population of Britain as a whole (11 percent; table 3$)$.

\section{$A$ 'student' effect?}

It is possible that the ethnic differences in levels of residential mobility observed in Table 5 are a result of characteristics of ethnic groups other than age and sex rather than anything to do with ethnic group per se. To test this, propensity to migrate was predicted via logistic regression with ethnic group and student status as independent variables of particular interest and socio-economic classification, sex, tenure, qualifications, immigrants status, whether an individual has children and partnership status as control variables. The results are displayed in Table 6 . The model confirms the patterns of table 5 in showing that the most mobile young adults are White British and students. These findings are statistically significant after accounting for other characteristics of young adults. In addition, the model confirms that gender does significantly differentiate between mobility with females having higher odds of migrating than males. The most mobile were also managers and professionals, private renters, those with A level (further education) qualifications or above, immigrants, with children and in cohabiting partnerships.

These results generally confirm what has been found in other studies (See, for example, Hamnett, 1991; Champion and Fielding, 1992; Halfacree et al., 1992; Leon and Strachan, 1993; Brimblecombe et al., 1999; Bailey and Livingstone, 2005; Finney and Simpson, 2008) and lead to the question of whether the student effect is evident for each ethnic group. Table 7 presents results of interactions between ethnic group and student status displaying the results as probabilities of migrating. The addition of the interaction term has very little effect on the other coefficients in the model, as they are shown in Table 6. The interaction between ethnic group and student status is significant for the White British, Pakistani, Black African and Chinese ethnic group (and also the White Irish group but the main effect of ethnic group is not significant in this case). However, the effect of the interaction is not in the same direction for each of these groups. Specifically, being a student and White British 
Table 6. Odds of migrating within Britain for young adults (aged 16-29) predicted with student status, ethnicity and socioeconomic and demographic characteristics

\begin{tabular}{|c|c|c|c|c|c|}
\hline & & & & $95 \% \mathrm{CI}$ & \\
\hline & & Odds Ratio & $\mathrm{p}$ & Lower & Upper \\
\hline Constant & & 0.23 & & & \\
\hline Ethnic Group & White British & 1.00 & & & \\
\hline & White Irish & 1.00 & 0.94 & 0.91 & 1.11 \\
\hline & White Other & 0.86 & 0.00 & 0.81 & 0.92 \\
\hline & Mixed & 0.82 & 0.00 & 0.76 & 0.89 \\
\hline & Indian & 0.74 & 0.00 & 0.69 & 0.80 \\
\hline & Pakistani & 0.73 & 0.00 & 0.67 & 0.79 \\
\hline & Bangladeshi & 0.65 & 0.00 & 0.57 & 0.73 \\
\hline & Other Asian & 0.71 & 0.00 & 0.62 & 0.81 \\
\hline & Black Caribbean & 0.58 & 0.00 & 0.52 & 0.64 \\
\hline & Black African & 0.68 & 0.00 & 0.62 & 0.75 \\
\hline & Black Other & 0.54 & 0.00 & 0.43 & 0.67 \\
\hline & Chinese & 0.75 & 0.00 & 0.67 & 0.85 \\
\hline & Other & 0.85 & 0.02 & 0.74 & 0.97 \\
\hline Student Status & Non Student & 1.00 & & & \\
\hline & Student & 1.12 & 0.00 & 1.08 & 1.16 \\
\hline Socio-economic Classification & Managers and Professionals & 1.00 & & & \\
\hline & Intermediate Occupations & 0.93 & 0.00 & 0.90 & 0.96 \\
\hline & Semi-routine and Routine & 0.91 & 0.00 & 0.88 & 0.94 \\
\hline & Never Worked/Unknown & 0.73 & 0.00 & 0.70 & 0.75 \\
\hline Sex & Male & 1.00 & & & \\
\hline & Female & 1.09 & 0.00 & 1.07 & 1.12 \\
\hline Tenure & Home Owner & 1.00 & & & \\
\hline & Part rent, Part mortgage & 1.33 & 0.00 & 1.20 & 1.47 \\
\hline & Social Renter & 1.09 & 0.00 & 1.06 & 1.13 \\
\hline & Private Renter & 4.17 & 0.00 & 4.08 & 4.27 \\
\hline Qualifications & None up to GCSE & 1.00 & & & \\
\hline & A Level to Degree Level & 1.86 & .000 & 1.82 & 1.90 \\
\hline & Other or Unknown & 1.09 & .012 & 1.02 & 1.17 \\
\hline Immigrant Status & Non immigrant & 1.00 & & & \\
\hline & Immigrant & 1.28 & 0.00 & 1.22 & 1.34 \\
\hline Children & No Children & 1.00 & & & \\
\hline & Has Children & 1.13 & 0.00 & 1.10 & 1.16 \\
\hline Partnership Status & Single & 1.00 & & & \\
\hline & Married & 0.34 & 0.00 & 0.33 & 0.35 \\
\hline & Cohabiting & 1.30 & 0.00 & 1.27 & 1.34 \\
\hline
\end{tabular}

Source: 2001 UK Census Individual Sample of Anonymised Records. Internal migration is in period 2000-2001. Emboldened coefficients are significant at $\mathrm{p}<=0.05$. The pseudo $\mathrm{R}$ squared value (Nagelkerke) is 0.25 and the -2 Log Likelihood value is 60,287.0.

Notes: Reference category is White British, Manager/Professional, single, male, home owner, with qualifications up to GCSE level, not a student, born in UK, without children. Population: GB age 16-29 (excluding stulawy=1). 
or Chinese increases the probability of migrating within Britain, from 19 to 21 percent for White British young adults and from 14 to 21 percent for Chinese young adults. In contrast, for Pakistanis and Black Africans, being a student reduces the probability of residential mobility from 11 to 9 percent for Pakistani young adults and from 14 to 13 percent for Black African young adults.

It is plausible that these effects differ with age amongst these young adults because a different relationship can be expected between student status and migration at different educational stages. Young adults aged 19 and under who are students, predominantly in school or college, are likely to be resident in the family home; those aged 20-24 are most likely to be in Higher

Table 7. Effect of student status and ethnic group on young adults' propensity to migrate within Britain

\begin{tabular}{|c|c|c|c|c|c|c|}
\hline & \multicolumn{3}{|c|}{ Ethnic Group } & \multicolumn{3}{|c|}{$\begin{array}{l}\text { Student-Ethnic Group } \\
\text { interaction* }\end{array}$} \\
\hline & $\begin{array}{l}\text { Probability of } \\
\text { Migrating (\%) }\end{array}$ & $\mathrm{p}$ & B & $\begin{array}{l}\text { Probability of } \\
\text { Migrating (\%) }\end{array}$ & $\mathrm{p}$ & B \\
\hline White British & 19.28 & 0.00 & -1.43 & 21.48 & 0.00 & 0.14 \\
\hline White Irish & 17.94 & 0.23 & -0.09 & 26.39 & 0.01 & 0.36 \\
\hline White Other & 16.94 & 0.00 & -0.16 & 19.41 & 0.64 & 0.03 \\
\hline Mixed & 15.93 & 0.00 & -0.23 & 16.46 & 0.31 & -0.10 \\
\hline Indian & 14.31 & 0.00 & -0.36 & 14.92 & 0.29 & -0.09 \\
\hline Pakistani & 11.46 & 0.00 & -0.61 & 9.36 & 0.00 & -0.36 \\
\hline Bangladeshi & 9.34 & 0.00 & -0.84 & 8.03 & 0.07 & -0.30 \\
\hline Other Asian & 14.48 & 0.00 & -0.34 & 14.79 & 0.48 & -0.11 \\
\hline Black Caribbean & 11.30 & 0.00 & -0.63 & 10.12 & 0.07 & -0.26 \\
\hline Black African & 14.29 & 0.00 & -0.36 & 13.28 & 0.02 & -0.22 \\
\hline Black Other & 8.33 & 0.00 & -0.97 & 9.78 & 0.88 & 0.04 \\
\hline Chinese & 13.78 & 0.00 & -0.40 & 20.68 & 0.00 & 0.35 \\
\hline Other & 16.05 & 0.04 & -0.22 & 18.85 & 0.67 & 0.06 \\
\hline
\end{tabular}

Source: 2001 UK Census Individual Sample of Anonymised Records. Internal migration is in the period 2000-2001. Emboldened probabilities are significant at $\mathrm{p}<=0.05$. $\mathrm{P}$ is the probability of migrating for the specified characteristics, displayed as a percentage. Addition of the interaction terms has virtually no effect on the coefficients for the other variables in the model. It increases the pseudo R squared value from 0.251 to 0.253 and reduces the -2 Log Likelihood value from $60,287.0$ to $59,845.0$.

Notes: Reference category is White British, Manager/Professional, single, male, home owner, with qualifications up to GCSE level, not a student, born in UK, without children. Population: GB age 16-29 (excluding stulawy=1).

* Indicates an interaction between student status and ethnic group. The columns show the probabilities of migration calculated from the models when the interaction term is added, and represent the effect of being a student and in particular ethnic groups additional to the separate effects of student status and ethnic group. 
Education (University) and independently resident; those aged 25-29 can be considered mature students and are more likely to be living in their own family home. For these three age groups, differences in mobility between students and non-students can be theorised to be greatest for the 20-24 year olds because of the association of Higher Education study with high levels of residential transience.

Table 8 repeats the interactions between ethnic group and student status shown Table 7 separately for the 16-19, 20-24 and 25-29 age groups. Being a student and in a particular ethnic group is not a significant predictor of propensity to migrate for 16-19 year olds for any ethnic group. For the 25-29 year olds, being a student increases residential mobility for White British but does not have an ethnic-specific effect for any other group. For the 20-24 year old age group, however, being a student has ethnic-specific effects for several groups: it increases residential mobility for the White British group but reduces residential mobility for the Pakistani, Black Caribbean and Black

Table 8. Effect of student status and ethnic group on propensity to migrate within Britain by age (16-19, 20-24, 25-29), probabilities of migrating (\%)

\begin{tabular}{|c|c|c|c|c|c|c|}
\hline & \multicolumn{2}{|c|}{$16-19$} & \multicolumn{2}{|c|}{$20-24$} & \multicolumn{2}{|c|}{$25-29$} \\
\hline & $\begin{array}{l}\text { Ethnic } \\
\text { Group }\end{array}$ & $\begin{array}{l}\text { Student- } \\
\text { Ethnic } \\
\text { Group } \\
\text { interaction* }\end{array}$ & $\begin{array}{l}\text { Ethnic } \\
\text { Group }\end{array}$ & $\begin{array}{l}\text { Student- } \\
\text { Ethnic } \\
\text { Group } \\
\text { interaction* }\end{array}$ & $\begin{array}{l}\text { Ethnic } \\
\text { Group }\end{array}$ & $\begin{array}{l}\text { Student- } \\
\text { Ethnic } \\
\text { Group } \\
\text { interaction }\end{array}$ \\
\hline White British & 13.6 & 13.1 & 24.9 & 31.2 & 22.7 & 28.4 \\
\hline White Irish & 17.8 & 18.2 & 23.9 & 28.9 & 22.1 & 45.1 \\
\hline White Other & 13.1 & 9.4 & 25.5 & 25.1 & 21.8 & 25.7 \\
\hline Mixed & 9.6 & 9.3 & 20.2 & 25.4 & 21.0 & 23.8 \\
\hline Indian & 9.7 & 9.6 & 18.0 & 19.7 & 16.2 & 18.5 \\
\hline Pakistani & 6.5 & 4.7 & 15.4 & 13.5 & 13.6 & 15.2 \\
\hline Bangladeshi & 6.2 & 5.9 & 9.3 & 7.7 & 14.1 & 12.4 \\
\hline Other Asian & 13.1 & 8.4 & 15.1 & 19.1 & 20.2 & 19.2 \\
\hline Black Caribbean & 8.7 & 7.4 & 14.4 & 11.7 & 13.8 & 15.1 \\
\hline Black African & 7.0 & 7.1 & 19.2 & 16.4 & 19.5 & 21.3 \\
\hline Black Other & 7.0 & 6.0 & 12.0 & 15.0 & 7.3 & 10.9 \\
\hline Chinese & 10.9 & 13.6 & 18.6 & 23.6 & 16.5 & 25.3 \\
\hline Other & 17.2 & 16.2 & 17.6 & 18.5 & 22.4 & 28.7 \\
\hline
\end{tabular}

Source: 2001 UK Census Individual Sample of Anonymised Records. Internal migration is in the period 2000-2001. Emboldened probabilities are significant at $\mathrm{p}<=0.05$. Figures presented are $\mathrm{P}$, the probability of migrating for the specified characteristics, displayed as a percentage, calculated from the B values predicted by the models.

Notes: Reference category is White British, Manager/Professional, single, male, home owner, with qualifications up to GCSE level, not a student, born in UK, without children. Population: GB (excluding stulawy=1). Age groups are modelled separately.

* Indicates an interaction between student status and ethnic group, for each age group. 
African groups. This tells us that the ethnic-specific effects of being a student observed in Table 7 are predominantly being driven by the experiences of the 20 to 24 year olds.

\section{A student-gender effect?}

We have already seen that females are more mobile than males (Table 6) and that something curious is happening in terms of low residential mobility for Pakistani females who are mature students (age 25-29, Table 5). Table 9 presents models that examine whether being female and a student and in each ethnic group has an additional effect on propensity to migrate. Result for separate ethnic group models are presented as probabilities of migrating. For most ethnic groups there is no significant additional effect on propensity to migrate of being both female and a student. However, for the White British and Pakistani young adults being a female and a student matters for migration within Britain. Young adult White British females who are students have

Table 9. Effect of being female and student status on propensity to migrate within Britain by ethnic group, probabilities of migrating (\%)

\begin{tabular}{lccccc}
\hline & & \multicolumn{3}{c}{ Female-Student } \\
& Reference & Female & Student & interaction* & Pseudo R squared \\
\hline White British & 19.1 & 20.8 & 22.5 & 22.0 & 25.9 \\
Pakistani & 11.2 & 10.8 & 13.3 & 8.0 & 13.9 \\
White Irish & 18.9 & 24.5 & 24.1 & 28.0 & 24.7 \\
White Other & 22.0 & 22.9 & 22.2 & 25.0 & 15.2 \\
Mixed & 15.6 & 51.1 & 60.1 & 15.6 & 21.7 \\
Indian & 11.3 & 12.2 & 12.7 & 11.9 & 26.5 \\
Bangladeshi & 13.7 & 22.4 & 15.6 & 16.7 & 8.9 \\
Other Asian & 17.0 & 18.5 & 15.8 & 14.3 & 17.7 \\
Black Caribbean & 11.9 & 13.4 & 9.3 & 12.3 & 13.0 \\
Black African & 21.1 & 13.9 & 12.3 & 17.1 & 15.4 \\
Black Other & 11.5 & 8.3 & 7.9 & 9.6 & 19.3 \\
Chinese & 13.3 & 14.0 & 16.2 & 18.6 & 30.5 \\
Other & 19.4 & 26.0 & 24.4 & 23.5 & 18.2 \\
\hline
\end{tabular}

Source: 2001 UK Census Individual Sample of Anonymised Records. Internal migration is in period 2000-2001. Emboldened coefficients are significant at $\mathrm{p}<=0.05$. $\mathrm{P}$ is the probability of migrating for the specified characteristics, displayed as a percentage. Coefficients for variables in the model that are not shown act in the same way as results presented in Table II. Ethnic groups for whom none of the sex interactions were statistically significant have not been included in the table.

Notes: Reference category is Manager/Professional, single, male, home owner, with qualifications up to GCSE level, not a student, born in UK, without children. Population: GB age 16-29 (excluding stulawy=1).

* Indicates an interaction between being a female and a student, in each ethnic group. 
a 22 percent probability of migrating. This is higher than the probability of migrating for White British males who are not students (19 percent) and White British females who are not students (21 percent) but slightly lower than the probability of migrating for White British males who are students (22 percent). Young adult Pakistani females who are students have an 8 percent probability of migrating (slightly higher than that suggested by Table 5). This is lower than Pakistani males and females who are not students and Pakistani males who are students, confirming the observation from Table 5.

\section{Discussion and conclusion}

This paper has aimed to improve our understanding of what is it about ethnicity that matters for residential mobility and, by extension, what it is about ethnicity that shapes residential choice and sub-national geographical distributions of ethnic group populations. It has been proposed that the heritage, culture and traditions associated with being a member of an ethnic group shape migration decisions at specific key junctures in the lifecourse. One such juncture in the UK context is movement to higher education which is a common homeleaving pathway for young adults in Britain. This paper has examined whether there are ethnic-specific associations between student status and residential mobility, and whether these vary according to age and gender.

The results have shown, first, that students of minority ethnic groups were less mobile than their White British counterparts and second, that being a student is differently associated with internal migration for White British and Chinese young adults compared with their South Asian and Black counterparts. The effect of student status was age-specific which is unsurprising given the strong tendency for undergraduate study in Britain to be undertaken immediately following the completion of further/school education at age $18 / 19$. Thus, student status was statistically significant for predicting internal migration for 20-24 year olds, not at all for 16-19 year olds and only for the White British for those aged 25-29.

For the White British and Chinese groups being a student mattered; it was associated with increased residential mobility for these young adults. This effect was particularly strong for Chinese students whose probability of migrating was 21 percent compared to 14 percent for Chinese young adults who were not students (other characteristics held constant). For Pakistani, Black Caribbean and Black African young adults, however, being a student reduced residential mobility compared with not being a student. For Pakistani young adults, being a female student reduced residential mobility even further.

These variations in the association between student status and internal migration suggest different student housing traditions across ethnic groups. The general expectation of university education meaning a move away from home and moves each year into new accommodation appears to be applicable to only White British and Chinese young adults. Indeed, it seems that the concept of students as mobile needs adapting when thinking about ethnic groups 
other than White British or Chinese. Student residential stability characterises the experience of Pakistani, Black Caribbean and Black African young adults and these differences may well be accentuated as changes to university funding take effect.

There are several potential explanations for the ethnic differences in student mobility. Following Connor et al. (2004), it can be speculated that Pakistani, particularly female Pakistani, and Black students tend to remain within the family home while studying. This may be a desire to remain close to family networks which are particularly important for some ethnic groups (Mulder, 2007; Phillips, 2006) and also a means by which to reduce the overall cost of higher education. Remaining in the family home may be particularly common for students who Ball et al. (2002) identify as 'contingent choosers' which would broadly be the group targeted by the widening participation agenda.

If students of Pakistani ethnic group, particularly females, and Black ethnic groups are, more than other young adults, narrowing their university choice options according to accessibility from home this raises questions about equality of access to higher education and differential opportunity in the graduate job market (Faggian et al., 2007). This constraint on choice is likely to disproportionately affect the students of these ethnic groups who are in lower socio-economic groups with less means to fund higher education. Here we reach the important issue of the intersect between ethnicity and class (Reay et al., 2001) and the difficulty of intergenerational upward social mobility if access to higher education is restricted by residential stability (Brooks, 2003).

An alternative understanding of why residential mobility is reduced for Pakistani and Black students but increased for White and Chinese students is a geographical one in two senses. First, Pakistani and Black populations are over-represented in urban centres, particularly Pakistanis in cities of the north of England and Blacks in London. These regions also host a large number of higher education institutions spanning the spectrum of 'new' and 'old'. It may be that choice is sufficient in these areas that it is not necessary for Pakistani and Black students to look further afield unlike their non-student contemporaries who may find it necessary to migrate for work opportunities.

The second geographical explanation is that suggested by Ball et all (2002), that perceptions of place differ between ethnic groups with respect to desirability of ethnic mix and the extent of socio-spatial horizons. Preference for certain universities may partly be based on perceptions of the ethnic mix of the population (as Feijten and van Ham, 2009 suggest for internal migration more generally). Shortlisting of potential places of study may be influenced by previous experience and the extent of social networks which, it could be argued, are more geographically dispersed for ethnic groups, such as White and Chinese, who are themselves more geographically dispersed.

These interpretations are speculative based on the results presented in this paper which are an initial exploration of ethnic-specific student mobility. Further quantitative analysis is necessary but difficult because of the absence 
of appropriate longitudinal data. This is not a new problem: in 1992 Coleman and Salt (1992: 400) commented that «the general lack of longitudinal data is a major vacuum in understanding British migration». Given the social and political as well as academic interest in migration and immigrant integration it is rather surprising that these data do not exist.

The data deficiency will be somewhat addressed by the newly formed UK Household Longitudinal Study, Understanding Society, a panel study of 100,000 individuals (40,000 households) with an ethnic minority boost of 3,000 households ${ }^{3}$ and a first wave module of questions on migration history. In a climate of reduced resources for large scale data collection, and debate about the future of the UK census, it is important that migration scholars continue to argue for migration's place within large scale social datasets.

Any quantitative development of the ideas raised here would undoubtedly be enhanced by the integration of qualitative work to investigate migration decision making processes and personal experiences of migration in young adulthood. Further work that aims to understand the motivations and constraints behind internal migration patterns, and any ethnic inequality or discrimination that they represent, will enable debates to move beyond assumptions of ethnic division and get at what it really is about ethnicity that matters for migration within Britain.

It appears that ethnicity does matter for residential mobility. It is likely that the ways in which it matters are multiple and complex. Without understanding the forces shaping migration patterns for different ethnic groups it is difficult to fully understand the social meaning of ethnic residential concentrations. Despite political discourses demonising ethnic clustering (see Finney and Simpson, 2009), academics have long recognised that the relation between social and residential segregation is complex (Bolt et al., 2010). Thus, ethnic convergence in geographical distribution or migration patterns cannot be expected, or used as an indicator of integration, because ethnicity continues to affect life decisions including residential mobility.

\section{References}

Aspinall, P. (2000). «The challenges of measuring the ethno-cultural diversity of Britain in the new millennium». Politics and Policy, 28 (1), 109-118.

Bailey, A. (2009). "Population geography: lifecourse matters Progress». Human Geography, 33 (3), 407-418.

Bailey, A. and Boyle, P. (2004). «Untying and Retying family Migration in the New Europe. Journal of Ethnic and Migration Studies, 30 (2), 229-241.

Bailey, N. and Livingstone, M. (2005). "Determinants of individual migration: an analysis of SARs Data». SCRSJ Working Paper, 3. Accessed October 2010: http://www.scrsj.ac.uk/media/media_69695_en.pdf

3. For further information see http://www.understandingsociety.org.uk/. The first data from the survey are due for release in 2010 but were not available at the time of writing. 
Ball, S.J.; Reay, D. and David, M. (2002). "Ethnic Choosing: minority ethnic students, social class and higher education choice». Race Ethnicity and Education, 5 (4), 333-357.

Bolt G.; Sule Ozuekren, A. and Phillips, D. (2010). «Linking integration and residential segregation». Journal of Ethnic and Migration Studies, 36 (2), 169-186.

Bonney, N.; McCleery, A. and Forster, E. (1999). "Migration, marriage and life course: commitment and residential mobility». In: Boyle, P. and Halfacree, K. (eds.). Migration and Gender in the Developed World. London: Routledge, 136-150.

Brimblecombe, N.; Dorling, D. and Shaw, M. (1999). "Mortality and migration in Britain, first results from the British Household Panel Survey». Social Science and Medicine, 49, 981-988.

Broecke, S. and Nicholls, T. (no date). «Ethnicity and Degree Attainment». Department for Education and Skills, Reearch Report RW92.

Brooks, R. (2003). "Young people's Higher Education Choices: the role of family and friends». British Journal of Sociology of Education, 24 (3), 283-297.

Burton, J.; Nandi, A. and Platt, T. (2010). «Measuring ethnicity: challenges and opportunities for survey research". Ethnic and Racial Studies, 33 (8), 1332-1349.

Cameron, D. (2011). Speech at Munich Security Conference. Munich, 5th February 2011.

Cantle, T. (2001). Community Cohesion: A Report of the Independent Review Team. London: Home Office.

Champion, T. and Fielding, T. (1992) (eds.). Migration processes and patterns, vol. 1. Research progress and prospects Belhaven, London.

Coleman, D. and Salt, J. (1992). The British Population: Pattern, Trends and Processes. Oxford: Oxford University Press.

Connor, H.; Tyers, C.; Modood, T. and Hillage, J. (2004). «Why the Difference? A closer look at higher Education Minority Students and Graduates». Research Report, 552. Institute for Employment Studies.

De VALK, H. (2007). «Living arrangements of migrant and Dutch young adults: The family influence disentangled». Population Studies, 61 (2), 201-217.

Equality Challenge Unit (2009). Statistical Report 2009, http://www.ecu.ac.uk/ publications/equality-in-he-stats-09

Faggian, A.; McCann, P. and Sheppard, S. (2006). "An analysis of ethnic differences in UK graduate migration behaviour». Annals of Regional Science, 40, 461-471.

- (2007). «Some evidenced that women are more mobile than men: gender differences in UK graduate migration behaviour». Journal of Regional Science, 47 (3), 517-539.

Feijten, P. and Van Ham, M. (2009). "Neighbourhood change... reason to leave?». Urban Studies, 46, 2103-2122.

FinNeY, N. (forthcoming, 2011). "Understanding ethnic differences in migration of young adults within Britain from a lifecourse perspective». Transactions of the Institute of British Geographers.

Finney, N. and Simpson, L. (2008). «Internal Migration and Ethnic Groups: Evidence for Britain from the 2001 Census». Population Space and Place, 14, 63-83.

- (2009). Sleepwalking to segregation? Challenging myths about race and migration. Bristol: The Policy Press.

- (2009). «Population dynamics: the roles of natural change and migration in producing the ethnic mosaic». Journal of Ethnic and Migration Studies, 35 (9), 1479-1496.

Fussell, E.; Gauthier, A.H. and Evans, A. (2007). «Heterogeneity in the Transition to Adulthood: The Cases of Australia, Canada, and the United States». European Journal of Population, 23, 239-414. 
Gauthier, A.H. (2007). «Becoming a Young Adult: An International Perspective on the Transition to Adulthood». European Journal of Population, 23, 217-223.

Goldschneider, C. and Goldschneider, F.K. (1988). "Ethnicity, Religiosity and Leaving Home: The Structural and Cultural Bases of Traditional Family». Values Sociological Forum, 3 (4), 525-547.

Goldschneider, F.K. and Goldschneider, C. (1997). "The Historical Trajectory of the Black Family: Ethnic Differences in Leaving Home over the Twentieth Century». The History of the Family, 2 (3), 295-307.

Halfacree, K.; Flowerdew, R. and Johnson, J. (1992). "The characteristics of British migrants in the 1990s: evidence from a new survey». The Geographical Journal, 158 (2), 157-169.

HamnetT, C. (1991). "The relationship between residential migration and housing tenure in London 1971-1981: a longitudinal analysis». Environment and Planning A, 23 (8), 1147-1162.

HEFCE (2009). Strategic Plan 2006-2011, http://www.hefce.ac.uk/pubs/

- (2010). «Student ethnicity. Profile and progression of entrants to full-time. First degree study. Issues paper, 13, http://www.hefce.ac.uk/pubs/

Hopkins, P. and Pain, R. (2007). "Geographies of age: thinking relationally». Area, 39 (3), 287-294.

Hosmer, D.W. and Lemeshow, S. (2000). Applied Logistic Regression (2 ${ }^{\text {nd }}$ edition). New York: Wiley.

Johnston, R.; Forrest, J. and Poulsen, M. (2002). «Are there ethnic elcaves / ghettos in English cities?». Urban Studies, 39 (4), 591-698.

Kalra, V. and Kapoor, N. (2009). "Interrogating Segregation, Integration and the Community Cohesion Agenda». Journal of Ethnic and Migration Studies, http://www.informaworld.com/smpp/title $\sim \mathrm{db}=\mathrm{all} \sim$ content $=\mathrm{t} 713433350 \sim \mathrm{tab}=$ issueslist - branches=35 - v3535 (Issue 9 November 2009), 1397-1415.

Kulu, H. and Milewski, N. (2007). «Family change and migration in the life course: An introduction». Demographic Research, 17 (19), 567-590.

LeON, D. and Strachan, D. (1993). «Socioeconomic characteristics of interregional migrants in England and Wales, 1939-1971». Environment and Planning A, 25, 1441-1451.

Mitchell, B.A.; Wister, A.V. and Gee, E.M. (2004). «The Ethnic and Family Nexus of Homeleaving and Returning Among Canadian Young Adults». The Canadian Journal of Sociology, 29 (4), 543-575.

Mortimer, J.T. and Shanaham, M.J. (2004) (Eds). Handbook of the life course. New York: Springer.

Mulder, C.H. (2007). "The family context and residential choice: a challenge for new research». Population, Space and Place, 13, 265-278.

Mulder, C.H. and Wagner, M. (1993). «Migration and Marriage in the Life Course: a Method for Studying Synchronised Events». European Journal of Population, 9, 55-76.

Muñoz, S. (2010). "Geographies of Faith: the differing residential patterns of the Indian-Hindu, Indian-Sikh and Indian-Muslim populations of Dundee and Glasgow». Population, Space and Place, 16 (4), 269-285.

PEACH, C. (2009). «Slippery Segregation: Discovering or Manufacturing Ghettos?». Journal of Ethnic and Migration Studies, 35 (9), 1381-1395.

Phillips, D. (2006). «Parallel lives? Challenging discourses of British Muslim selfsegregation». Environment and Planning D: Society and Space, 24 (1), 25-40. 
Phillips, T. (2005). «After 7/7: sleepwalking to segregation Speech». Manchester Council for Community Relations 22 September.

RABE, Birgitta and TAYLOR, Mark (2010). «Residential mobility, neighbourhood quality and life-course events». Journal of the Royal Statistical Society Series A (Statistics in Society), 173 (3), 531-555.

Reay, D.; Davies, J.; David, M. and Bali, S.J. (2001). «Choices of Degree or Degres of Choice? Class, 'Race' and the Higher Education Choice Process». Sociology, 35 (4), 855-874.

Simon. A. (2010). «Do ethnic groups migrate towards areas of high concentration of their own group within England and Wales?». In: STIllwell, J. and van Ham, M. (eds.). Ethnicity and Integration Understanding Population Trends and Processes, 3. Dordrecht: Springer.

Simpson, L. (2007). "Ghettos of the mind: the empirical behaviour of indices of segregation and diversity». Journal of the Royal Statistical Society Series A (Statistics in Society), 170 (2), 405-424.

Simpson, L. and Finney, N. (2009). «Spatial patterns of Internal Migration: Evidence for Ethnic Groups in Britain Population». Space and Place, 15, 37-56.

- (2009). "Spatial patterns of Internal Migration: Evidence for Ethnic Groups in Britain». Population, Space and Place, 15, 37-56.

Simpson, L.; Gavalas, V. and Finney, N. (2008). «Population dynamics in ethnically diverse towns: the long-term implications of immigration». Urban Studies, 45 (1), 163-184.

Smith, D.P. and Holt, L. (2007). «Studentification and apprentice gentrifiers within Britain's provincial towns and cities: extending the meaning of gentrification». Environment and Planning A, 39 (1), 142-161.

Stillwell, J. (2010). «Internal Migration Propensities and Patterns of London's Ethnic Group». In: Stillwell, John; Duke-Williams, Oliver and Dennett, Adam (Eds.). Technologies for Migration and Commuting Analysis: Spatial Interaction Data Applications, 175-195.

Stillwell, J. and Hussain, S. (2008). «Ethnic group migration within Britain during 2000-01: a district level analysis». Working Paper. Leeds: University of Leeds School of Geography.

Thomas, B. and Dorling, D. (2007). Identity in Britain. A cradle-to-grave atlas. Bristol: The Policy Press. 